\title{
AUSTERITY, GLOBALISATION AND ALTERNATIVES
}

\begin{abstract}
Resumo: Este artigo sustenta que austeridade não é algo necessário ou externamente determinado, mas um projeto de classe ativo e uma escolha ideológica de elites e dos poderosos. Há alternativas à austeridade. Uma delas baseia-se em igualdade e em direitos sociais e econômicos. Outras envolvem a reestruturação do trabalho para uma sociedade baseada no trabalho precariamente remunerado, e a liberdade de movimento em uma sociedade global de fronteiras abertas. Elas ajudariam a contestar a austeridade, implicando, elas próprias, benefícios.
\end{abstract}

Palavras-chave: austeridade, globalização, trabalho, movimento livre, igualdade.

\begin{abstract}
This article argues that austerity is not necessary or externally determined. It is an active class project and an ideological choice of elites and the powerful. There are alternatives to austerity. One is based around equality and economic and social rights. Others involve the restructuring of work to a society based on less paid work, and freedom of movement in a global society of open borders. These would help counter austerity and have benefits of their own.
\end{abstract}

Keywords: austerity, globalisation, work, free movement, equality.

This article is about austerity in the context of globalisation and in terms of alternatives. The financial crisis called current global capitalism into question, at least or especially in its neoliberal forms, perhaps even fundamentally. Yet despite that challenge, ideas of alternative types of economy and society to what we have and to what led to austerity have barely been on the political agenda in a practical sense in the aftermath of the world financial crisis and austerity policies that followed. I am honoured to be able to contribute to this issue for Octavio Ianni and I hope

* Professor of Political Sociology at the University of Sussex, Brighton, United Kingdom. Email: 1.martell@sussex.ac.uk. 
this discussion of these themes echoes with the global, social and political concerns he pursued in his own career.

Austerity has a lot to do with globalisation, not just in terms of the global nature of the financial crisis, but also the solutions that can be pursued. Global political regulation is not suitable for pursuing an alternative, but in another more marginalised form globalisation is. I wish to discuss three alternatives to austerity. One more mainstream alternative did not become dominant in Europe despite the chances it had as a result of the financial crisis. The other two have been marginal for a long time and shunned by conventional politics. But they offer good alternatives to austerity and so austerity gives us the chance to assess them anew. And they have strong merits in their own right.

Much of the discussion of austerity has focused on Southern European countries, where conditions have been especially harsh and the troika have played a major role. I want to also refer to examples from the UK. This is partly because this is my country and the one I know best. But it is also because austerity policies are being pursued in the UK without the external intervention of the troika. It shows that austerity is not just about external transnational agencies, a kind of political globalisation, undermining national democracy. It is also about national elites being complicit in austerity, and in the southern European countries as well asthe UK.

Post-financial crisis policies of austerity in Europe are not a new and unique thing to this time and place. They echo neoliberal policies global agencies and states have pursued in Latin America, in developing countries and many parts of the world, especially since the 1980s. Austerity as a political choice, and the political responses to it, is part of this larger story. It is also a story of power, ideology and inequality. 


\section{Discourses of austerity}

Austerity has monopolised the political agenda in Europe, and has not gone without a presence or effects in other places. It has done so in a situation where an agenda for equality and rights should have had a chance. The financial crisis provided an opportunity and case for greater regulation of finance and capital, and the taxation of finance for global social ends. This was on the basis of a popular political mood in the aftermath of the crisis against, or at least very questioning of, the banking sector, finance and bankers as individuals.

But this path hasn't been taken because those in power are not ideologically open to it, and are more committed to supporting the interests of corporations and capital than an approach that tries to regulate them or restructure capitalism towards more equal and social goals. Austerity has been presented as a necessity, deficit reduction being required, with no other alternative possible in the post-financial crisis context. It is said to be a technical solution, the choice being between different technocratic political actors.

This has echoes of older discourses about globalisation where neoliberal politics were said to be the only possible way. In these it was argued that capital mobility rules out a social democratic politics of taxation, regulation, welfare and redistribution. Such policies do not serve the interests of capital, which governments need to keep in their countries, and which is deterred by social democracy. But we should have learned from this previous story. Neoliberal politics are not necessitated by economic globalisation. The Latin American left have pursued alternatives in a global context, and not everyone has gone down the route of AngloAmerican capitalism. Competition between states in a race to the bottom to attract global capital is not determined (as MOSLEY 2005 has outlined). The same goes now for austerity politics, which are not a necessity but an ideological and class project, pursuing a particular ideological approach because of a political commitment to it, not compulsion, and in support of the interests of specific actors and sectors of society against others. 
It's important to look at the discourse of austerity because discourses are used to mobilise people behind projects and create an ideological hegemony for a particular approach. Drawing on Gramsci, Stuart Hall argued for the importance of hegemonic politics in the era of 1980s neoliberalism (HALL; JACQUES, 1983; HALL, 1988). Before then social democratic approaches to do with Keynesianism and welfare had support across the political spectrum. Since the 1970s and ' 80 s neo-liberalism has had more of a hegemonic role in the political sphere ${ }^{1}$. It has not been alldominant and in society has not always swung people behind it. But it has had a leading and increasingly dominant role in the political sphere pulling the political agenda and centre to the right, especially the economically liberal right.

Austerity discourse has tried to take neoliberal hegemony further and extend it into areas where it had not intruded so far before. It represents the private sector, rich and right against the public sector and poor ${ }^{2}$. As such austerity is a class and ideological approach. It sets up the problem behind deficits as spending on a public sector that is too big and bloated. Through welfare and social payments government are seen to be rewarding the inefficient and lazy, and welfare is presented as being given to the undeserving and scrounging. The poor and welfare recipients are divided from people seen as hard-working and deserving. This division between them and the lazy recipients of public sector support, or even its workers, becomes extended to a division between the domestic population and immigrants. It is transported into an anti-immigration discourse in which the home population is hard working and deserving whereas immigrants are after something for nothing, free health and welfare.

In these ways the more powerful and rich who are behind the financial crisis have shifted blame on to the weaker and poorer

\footnotetext{
1 Tony Judt (2010) has outlined this history and current circumstances of social democracy well.

${ }^{2}$ I am drawing on New Economics Foundation's (2013) discussion of austerity and possible anti-austerity discourses here.
} 
who were not its cause. The British Prime Minister has managed to move responsibility for the deficit from finance and the nature of financial capitalism to the previous Labour government who spent to bail out the banks and provide money in the economy to avoid an even greater recession than we got and economic collapse. Labour espouses austerity policies, just slower and less radically, wanting to be seen as a party of cuts and reductions in the public sector and raising doubts about immigration ${ }^{3}$.

\section{Austerity, Inequalities and Rights}

Austerity policies have expanded inequalities and undermined rights. Capital has been bailed out rather than blamed for a crisis rooted in the way finance behaves in an economically liberal capitalism. Regulation and reforms to taxation, including on bankers bonuses and financial transactions, have not been taken up in a structurally significant way. Capital has maintained or even solidified power in a period when it has been under question. Disparities in income have widened, the poorest getting poorer as welfare support declines and incomes are cut, while the rich continue accumulating income and wealth.

Social rights have taken a hit. Areas such as health and education are increasingly marketised and privatised. In the UK the National Health Service is organised more around market principles. In higher education students now pay the full cost of their education and universities are run like businesses oriented around money, under top-down management, students as consumers and staff as the recipients of directives (a good outline of these changes is by COLLINI, 2013). Universities are much less institutions about educational values, based on collegiality and the

\footnotetext{
${ }^{3}$ British Social Attitudes surveys show a mixed response by the UK public to austerity issues, over time and according to policy issue, but with evidence of declining support for social welfare since New Labour came to power - see Park et al $(2012,2013)$.
} 
citizenship of staff and students. The neoliberalism of the 1980s and after was about deregulating and privatising the economy but austerity policies are now taking privatisation and marketisation into the heart of social democracy, the public sector.

Ideologically conservative and neoliberal ideology is being normalised, and welfare and liberalism in its social and political forms further marginalised. Nowadays preference for the private sector and the market is a default position, which is accepted unless the case can be made otherwise. The case of state welfare or social liberalism is increasingly beyond the norm and mainstream and has to be fought for. Political and civil rights have been under threat, as well as social rights. Protest has been met by heavyhanded policing. In the UK people arrested on protests have been given penalties and sentences harsher than they would have received in a non-political context. Student protestors face arrest and disciplinary charges. To some it appears that an attempt is being made to criminalise dissent.

These kinds of changes are happening in the UK and austerity policies are not just restricted to the southern European countries subject to demands from the troika. In short austerity is not just an issue of pressure from outside national boundaries. Where there is not a troika intervention the class politics of austerity are nevertheless being pursued. Austerity is not reducible to international constraints, it is also an approach of national elites, in the states subjected to troika interventions as well as in those not so.

\section{Equality against austerity}

I want to discuss three alternatives to austerity. Popular common sense has shifted to austerity as a norm. So alternatives will have to be fought for. One approach is to renew quite traditional policies. This will involve building a different discourse and account of austerity as the basis for an alternative set of 
policies that respond to the financial crisis and its aftermath (see New Economics Foundation, 2013).

In this approach, austerity needs to be explained as an ideological device, being used to justify an attack on the public sector and welfare for political reasons, and on the poor for class reasons. The alternative to austerity needs to say that the political right's objectives and class interests are being pursued and that they are sectional and with a particular agenda, not just technocratic, neutral or necessary. The alternative to austerity should say that we have to put the job of politics in the post-financial crisis era in the hands of a politics that is for the people as a whole.

An alternative discourse should say that the crisis is caused by an economy that encourages short-term, high-risk gambling by finance, unrestrained by regulation, in pursuit of personal gain. Therefore greater regulation is required and the economy needs restructuring for wider human needs. This is also a chance for an alternative discourse to question banks and the way they behave. The alternative can say that banks caused the problems, they set their own rules, yet were exempt from sanctions or responsibility for a crisis their behaviour seemed to be behind. For their failure they have been bailed out and, in fact, bonuses and rewards that bankers receive for the work they do are being maintained. Soon after the crisis hit, this way of explaining it was made widely and echoed with the public consciousness. Those pursuing a right-wing and class politics of austerity have managed to shift the agenda away, and an alternative to austerity needs to rescue this account as the basis for its own policies.

A critical discourse can explain austerity differently to the way its advocates and practitioners do. It's important to tell the story in an alternative way to provide the basis for alternative postcrisis policies.

The crisis is a chance to rediscover egalitarianism. The alternative can argue that the burden needs to be shared by all and not just by the weak, welfare recipients and the public sector who were not the cause behind it. The rich, finance and corporations should take more responsibility. In practice this means fairer taxes, 
on wealth and finance and from tax loopholes and havens. Fairer taxation can include financial transactions taxes that make a levy on the area of capitalism behind the crisis and ask it to make a contribution. Tax avoidance by big companies like Google and Amazon has been highlighted following the crisis so there is a basis for tightening and bolstering corporate taxes.

The revenue raised can be used to invest in jobs, infrastructure and the public sector. These are worthwhile areas in themselves that with investment can also boost growth, in the tradition of stimulus economics. A more social Europe can be built. Social democracy across Europe used to be seen as the basis for proliferating social rights and protections. But in power social democracy has tended to focus on economic deregulation across the EU, for instance in the late 1990s when social democratic parties held office across the continent. The social consequences of the crisis allow for the case for a more social Europe.

This is a traditional kind of social democracy but shouldn't be dismissed for being backward looking. The important thing is to do what's right and whether that is something from the past, present or future should not be the basis for judgement. What matters is whether it is the right path to take, not if it is old or new. And an agenda that is about equality could not be more up to date for the current time where inequality is rising. The poor are taking a hit from austerity and getting poorer, the working class have been losing jobs yet the rich accumulating more. The financial crisis and austerity makes equality more relevant than ever and is what distinguishes the left from the right (as BOBBIO 1996 argues). Without it a left approach is not different from the right' $\mathrm{s}^{4}$.

Who will support such a politics? Guy Standing (2011) has talked about a group called the precariat. This is a class that goes across classes. It comprises those who live an insecure and precarious existence. They are not guaranteed a job for life but face a future of juggling across different kinds of work, and periods

\footnotetext{
${ }^{4}$ For statements for such an alternative to austerity see Alveset al (2012) and policies of the Party of the European Left highlighted by Nichols (2014).
} 
between jobs and without them. In the in-between periods they have to find ways to live, maybe making money for themselves or finding creative ways of filling their unemployed times, whether watching daytime TV, blogging, writing poetry, protesting, or learning new skills. Some in this group have been part of global protest and occupy (MASON, 2012). And amongst and alongside them are the socially excluded, the non-class of non-workers (GORZ, 1982). These groups want the social rights, public good and equality that were promoted under their parent's generations. Even the most radical of them campaign for a welfare state that older libertarian left generations criticised for its bureaucracy and paternalism.

\section{Restructuring Work}

What I have discussed is a traditional alternative of the left. But the crisis gives us the chance to rethink alternatives. A major part of the crisis is unemployment, especially amongst the young. Investment is one solution to unemployment. A less growthoriented approach is rethinking work and the redistribution of working time. Work can be redistributed from those who have it to those who don't, as a solution to unemployment. This is an alternative that asks many people to work less so others can work. It goes beyond fetishising hard work, by expecting people to value non-work, and puts an emphasis on quality of life $\mathrm{s}^{5}$.

Rethinking work, its redistribution and value, is not an easy message to sell. The left has been a movement for the working class and a central objective has been jobs and better pay and conditions. Work is often seen as the solution to poverty and exclusion. Marxists focus on overcoming alienation and exploitation through collective ownership of production. The emphasis is on the space where work happens. For many people work is fulfilling and gives us structure, purpose, an income and economic independence.

\footnotetext{
${ }^{5}$ An important advocate of this approach has been André Gorz (1982, 1985, 1989).
} 
But for others large parts of their jobs are pointless. Their work is a means to an end. It is compulsion-something that would not be done if it were not an economic necessity. It is a sphere of control where your labour is sold and for that period you are under the domination of an employer and managers. Many would like more time off work, to slow down, go part-time, have a greater sphere of their lives where they are autonomous from ownership and domination by someone else, and where they can do more fulfilling things than their work requires them to do.

Marx, Keynes, Gorz and Bertrand Russell have talked about technological advances and higher productivity that can allow less work (SPENCER, 2014). Technology can be productive enough to permit us to produce more in less time. Instead we use it to produce more and work the same or more to consume more. Less growth and production could help with lowering work hours, and they are also good for reducing carbon emissions, important to greens. Less work allows more time for self-directed, creative or social activities, care, relationships, and political activity. The latter is important for reviving a society of active citizenship and participation. The young precariat are using their enforced spare time to do some of these things ${ }^{6}$.

A society with less work sounds utopian. But utopianism is not a bad thing. It is about looking for a better place that does not yet exist ${ }^{7}$. Movements for working class enfranchisement and rights, and for rights on the basis of gender, sexuality and race seemed to have had impossible dreams, which became more concrete because people pursued their visions. And there are practical means for implementing a society with less work. A universal basic income would allow for more time free from work. Fairer taxes and redistribution can help fund it. Legislation on maximum working hours could be beefed up. There could be a

\footnotetext{
${ }^{6}$ New Economics Foundation (2013) is a clear policy-oriented statement of the case for a society with shorter working hours. See also Coote and Franklin (2013).

${ }^{7}$ There are many good works on utopianism, one of which is by the sociologist Ruth Levitas (1990).
} 
move from a minimum wage to a living wage so work pays better and we don't have to do so much of it.

The reduction in work being advocated is less work for all so the unemployed after the crisis and under austerity have some of that work. Nevertheless overall it involves a lower work society. Less work and lower growth is not right for all time and places. In the short term during austerity and in the developing world growth is important. But we should like redistributed work. It is about equality and solving unemployment. This includes gender equality because men in paid work will have more time for childcare. It allows for more time for involvement in politics and democracy. If you want a healthy public sphere this is important. It can bring quality of life benefits. And it is about the economy meeting human needs, rather than humans being subjected to the logic of the economy.

Who could be the groups to support this? Gorz's non-class of non-workers who have no work but can have some through the redistribution of work, and the modern day precariat, have an interested in a society of redistributed work. The young, disproportionately affected by unemployment and growing up under precarity, could be appealed to.

A reduction of working hours has been tried in France, and a criticism is that it will lower productivity and economic performance. How can you persuade people to accept lower incomes and standards of living, especially in countries under austerity where many workers have been subjected to pay cuts? But this is about long-term change. It is important to look at concrete experiences, but also not be defeated by problems in certain electoral cycles. A low work society requires structural and attitudinal transformation over time. Maintaining productivity should not be a reason against a lower work society when it causes serious ecological problems and restricts time for freedom. A longterm solution involvesrethinking productivity.

For the unemployed the restructuring of work would lead to a higher income. Less income for others who work less can 
be ameliorated by measures like a basic income so some of the hours of non-work are funded, redistribution, and a living wage. At the same time a long-term shift to a society in rich countries towards lower economic needs and so less income, and based on humansatisfactions beyond consumption, is a shift that needs attitudinal change over time. Maintaining or increasing income as a human goal needs to be questioned long term.

\section{Migration against austerity}

There is another way the left can rethink traditional categories to respond to the crisis and austerity. This is to do with the free movement of people. When we discuss globalisation we often talk about the global movement of capital or culture or the impositions of global political power. Yet one of the most undeveloped types of globalisation is the global movement of surely the most important thing - people. Less than $3 \%$ of the world's population are migrants, and many of those have crossed the nearest border from one poor country to another, rather than hundreds or thousands of kilometres to the rich North. This kind of globalisation has been restricted by borders and blocks.

The left is not only attached to work but parts promote antiimmigration. They are concerned with their working class base, its jobs, wages and housing. They see this class as within their own national boundaries and not people outside, even though they are also humans and often more needy. This is especially the way the social democratic centre-left sees things. The green and revolutionary left have been more internationalist about migration. Cosmopolitan political theory says we have obligations to all regardless of what political boundaries they live within ${ }^{8}$.

\footnotetext{
${ }^{8}$ Cole $(2012 \mathrm{a} ; 2012 \mathrm{~b})$ provides an ethical case for open borders and free migration. No One Is Illegal (2003) and Hayter (2000) give polemical and political arguments for this perspective.
} 
More immigration can help with the crisis. Immigration contributes to growth. It turns people who were unproductive and unemployed in their country of origin into employed and productive people in the places they go to. Immigrants pay tax, which funds public services and welfare, and supports the costs of an ageing population. Migrants in the UK are less likely to claim benefits than the British, in contrast to false stories that say the opposite. They spend their wages, which creates an economic stimulus, consumption and jobs in the country they have moved to. So immigration, like the redistribution of work, can be a solution to the crisis?.

It is argued that immigration can lead to wage cuts at the bottom of the income ladder. But this is done by employers, and is about their power and regulation of the labour market, not done by immigrants. For some the problem with immigration is a cultural and anthropological one and about migrants integrating into receiving cultures. But the history of human societies is of cultural change and progress through movement in and out. Cultural criticisms take the current situation arbitrarily as a fixed moment to stick to, and ignore that it itself came from migration and intermixing.

Migration is a freedom and human rights issue. People have criticised restrictions on the freedom of people in communist states to move out. But inconsistently they do not support the right of people to move into countries. We accept people who move from another region of our country looking for better life chances, but not those who happen to be born outside the boundaries of our state. Many are concerned about human freedoms of speech, assembly, and protest, but not a freedom of the most basic kind, the freedom to move.

Immigration is a global inequality issue about tackling the poverty and disadvantage of migrants and the places they come

\footnotetext{
${ }^{9}$ Economic and social arguments for immigration are made by Legrain (2009), Moses (2006) and Harris (2002).
} 
from. These freedom and disadvantage issues are ones we should be concerned about. And borders don't work. People find ways of crossing them. Making this illegal makes it more dangerous as people look for alternative and risky ways of doing it, as we have seen in the Mediterranean and on the US-Mexico border. When borders are relaxed, as in the EU, we don't see tidal waves of migration. With open borders many people would choose not to move, because of roots and expense.

We can open borders to help with austerity. Who would support such a project? In many countries there is majority hostility to immigration and politicians contribute to this to win votes, even though the consequences may be xenophobia and danger for migrants. But in the UK people are less opposed to some kinds of immigration than others. There is less hostility to international students and temporary and skilled migration than to permanent migration and asylum seekers. The young are much less opposed to immigration than the old, and over time the young become the middle-aged and the old. Those in areas with more immigrants are more open to migration. Beliefs about amounts, types and effects of immigration are often inaccurate and can be corrected. There is a social basis for pro-immigration policies which can contribute to growth out of the crisis, tax revenue and to public services that are being run down under austerity ${ }^{10}$.

Austerity, lower work and migration are about power, ideology and inequality. Austerity is a class and ideological project against the poor and public sector, disguised by discourse as technocracy. The alternative is an egalitarian project about the needs of all humans. Work is a site of domination and exploitation. Technology and productivity is used to drive up production, consumption and profits for capitalists, rather than give people freedom from compulsion and counter collective ecological crisis. One way to deal with this is through collective ownership and control. Another is by freedom from paid work for greater

\footnotetext{
${ }^{10} \mathrm{On}$ the complexity and mixture of social attitudes to migration see Park et $a l$, (2012) and Oxford Migration Observatory (2011).
} 
autonomy and human needs, and redistribution of working time to beat unemployment under austerity. Migration is a type of freedom and globalisation, inconsistently obstructed by the rich to keep out the poor, on the basis of arbitrary and xenophobic criteria about place of origin, nation or ethnicity and false information on its effects. Allowing free movement of humans helps to achieve liberty and equality and overcome the effects of financial crisis through an alternative to austerity.

There are generational differences in relation to austerity, work and migration. The young face a reduction in life chances compared to their parents because of the financial crisis and austerity policies. They experience especially high rates of unemployment and are more liberal about immigration. An egalitarian politics of anti-austerity, the redistribution of work and migration can appeal especially to the young and incorporate them into politics that many are alienated from.

\section{From here to there}

There are difficulties in pursuing anti-austerity as a national alternative. It is argued that a radical alternative politics will lead to capital fleeing and, in the case of traditional left stimulus economics, inflation. There is no doubt that capital's power of exit exerts a significant force over politics and the choices for political parties acting nationally. But this can be exaggerated. Radical alternatives have been pursued in Latin America, in a globalised context where countries rely on international investment, and not been subverted by capital ${ }^{11}$. It can be argued that this is because states like Venezuela have had resources that give them clout. This may be so, but it does not alter that they were able to follow radical politics in a global capitalist economy without largescale disinvestment. There is room to move in developed world

\footnotetext{
${ }^{11}$ For useful accounts of the Latin American left see Cameron and Hershberg (2010), Weylandet al (2010), Castañeda and Morales (2008) and Barrett et al (2008).
} 
economies and a social democratic framework of education, training, health care and other public services financed by taxation can be attractive for capital (MOSLEY, 2005). In a rich continent like Europe, with skilled labour and infrastructure, investment will always be attracted even if egalitarian alternatives are being pursued.

Cross-national collaboration to pursue anti-austerity politics through global governance or world cosmopolitan democracy (e.g. HELD, 2000) is too inclusive. There will be conflicts of interest and ideology between the range of actors involved that make it difficult to agree on political regulation. Stalemate or conflict will be solved by the most powerful holding sway. Climate change and world trade talks show the problems of conflict and power inequalities in global regulation.

Anti-austerity at a regional level, for example through the EU or with a pan-Latin-American scope, relies on a region having likeminded parties in power at the same time. Cross-national collaboration for alternatives to austerity needs to be less regionallyfocused, and more ideologically oriented to likeminded others. Chavez sought alliances where he could get them with international actors with whom he had shared views. This was within his region or beyond, and not global where there were too many conflicts of interest and ideology and powerful actors favouring neoliberalism. This approach of alliances beyond the nation-state involves a kind of ideologically selective internationalism ${ }^{12}$.

A focus on the political level risks the co-option of agendas by politicians, willing to sacrifice their ideas for power. They can take the discourse of alternatives to austerity and turn them into something different that disarms them. So we need to look also to civil society - through social movements, protest and experiments in alternatives ${ }^{13}$. This can include co-operatives under democratic control. Alternatives to the marketisation of universities exist in free universities, autonomous from the state and market, offering

\footnotetext{
${ }^{12} \mathrm{I}$ have discussed this in more detail in Martell (2011).

${ }^{13}$ A recent book on alternative forms of organization is Parker et al (2014).
} 
education for free, not for profit, and often under co-operative control ${ }^{14}$. The occupy movement has been addressing alternatives to finance capitalism and austerity, and in their organisation and practices offer a prefiguring of alternative societies. Antiausterity needs to build up in civil society independent of the bureaucratisation of political parties, but not without also pursuing chances for influence through party participation in the state.

\section{Conclusion}

I have discussed whether the globalised economy prevents national political alternatives to austerity, and I do not think that is the case. Global politics is not a solution, but selective internationalism is an important route. Part of the solution is a type of globalisation that is probably the least developed and the most obstructed - the free movement of people.

Austerity is not necessitated by international financial crisis or by external transnational political agencies. It's a class and ideological project and national elites are complicit or even agents in it and have made an active choice to go down a particular route. They play a part as much as international economics and political forces do.

There are alternatives. Some are old left ones, egalitarian and about economic and social rights, but no less relevant because of that. In fact equality, which distinguishes the left from the right, is more important than ever in a context of class politics and rising inequality. Other alternatives are about freedom from work and to move and require rethinking common assumptions and prejudices. These solutions would help with austerity. They also have benefits of their own.

Alternatives require us to fight back against structures of power, inequality and ideology, for a world that meets human

\footnotetext{
${ }^{14}$ One example is the Social Sciences Centre in Lincoln, UK, see Bonnett (2013) and Class War University (2013).
} 
needs, and for equality, free movement, and freedom from domination.

\section{Bibliografia}

ALVES, L. P. et al, For a European Socialist Alternative: The Manifesto, 2012, http://europeansocialistalternative.blogspot. co.uk/2012/02/le-texte.html.

BARRETT, P. et al (eds). The New Latin American Left: Utopia Reborn. London: Pluto Press, 2008.

BOBBIO, N. Left and Right: the Significance of a Political Distinction. Cambridge: Polity Press, 1996.

BONNETT, A. 'Something New in Freedom', Times Higher Education, 25 May 2013.

CAMERON, M.; HERSHBERG, E. (eds). Latin America's Left Turns: Politics, Policies and Trajectories of Change. London: Lynne Rienner, 2010.

CASTANEDA, J.; MORALES, M. (eds). Leftovers: Tales of the Latin American Left. London: Routledge, 2008.

CLASS WAR UNIVERSITY. 'Occupying the City with the Social Science Centre - an Interview with Mike Neary', Class War University, $2^{\text {nd }}$ September 2013, http://classwaru. org/2013/09/02/occupying-the-city-with-the-social-sciencecentre/.

COLE, P. 'Taking Moral Equality Seriously: Egalitarianism and Immigration Controls', Journal of International Political Theory, 8, 1-2, 121-134, 2012a.

. The Ethics of Open Borders, Talk delivered for the Conway Hall Ethical Society Sunday Morning Lecture Series, December 9th, 2012b. 
COLLINI, S. 'Sold Out', London Review of Books, 35, 20, pp. 3-12, 2013.

COOTE, A.; FRANKLIN, J. (eds). Time on our Side: Why We need a Shorter Working Week. London: New Economics Foundation, 2013.

GORZ, A. Farewell to the Working Class. London: Pluto Press, 1982. . Paths to Paradise: On the Liberation from Work. London: Pluto Press, 1985. . Critique of Economic Reason. London: Verso, 1989.

HALL, S.; JACQUES, M. The Politics of Thatcherism. London: Lawrence and Wishart, 1983.

HALL, S. The Hard Road to Renewal: Thatcherism and the Crisis of the Left. London: Lawrence and Wishart, 1988.

HARRIS, N. Thinking the Unthinkable: The ImmigrationMyth Exposed. London: I.B. Taurus, 2002.

HAYTER, T. (2000) Open Borders: The Case Against Immigration Controls. London: Pluto Press, 2004.

HELD, D. 'Regulating Globalization?', International Sociology, vol. 15, no. 2, pp. 394-408, 2000.

JUDT, T. Ill Fares the Land: A Treatise On Our Present Discontents. London: Allen Lane, 2010.

LEGRAIN, P. Immigrants: Your Country Needs Them. London: Abacus, 2009.

LEVITAS, R. The Concept of Utopia. Oxford: Peter Lang, 1990.

MARTELL, L. 'Cosmopolitanism and Global Politics', Political Quarterly, 82, 4, pp. 618-27, 2011.

MASON, P. Why it's Kicking Off Everywhere: The New Global Revolutions. London: Verso, 2012.

MOSES, J. International Migration: Globalization's Last Frontier. London: Zed Books, 2006. 
MOSLEY, L. 'Globalisation and the State: Still Room to Move?', New Political Economy, Vol. 10, N. 3, September 2005.

NEW ECONOMICS FOUNDATION. Framing the Economy: The Austerity Story. London: New Economics Foundation, 2013.

NICHOLS, D. 'Party of the European Left's fourth congress: building unity to build hope', Links: International Journal of Socialist Renewal, 24 ${ }^{\text {th }}$ February 2014, http://networkedblogs. com/U733q.

NO ONE IS ILLEGAL. No One is Illegal Manifesto, 2003, http://www. noii.org.uk/no-one-is-illegal-manifesto/.

OXFORD MIGRATION OBSERVATORY. Thinking Behind the Numbers: Understanding Public Opinion on Immigration in Britain. Oxford: OMO, 2011.

PARK, A. et al (eds). British Social Attitudes 29. London: NatCen Social Research, 2012.

- British Social Attitudes 30. London: NatCen Social Research, 2013.

PARKER, M. et al (eds). The Routledge Companion to Alternative Organization. Abingdon: Routledge, 2014.

SPENCER, D. 'The Case for Working Less', The Conversation, 27 January 2014, https://theconversation.com/the-case-forworking-less-22454.

STANDING, G. The Precariat: The New Dangerous Class. London: Bloomsbury, 2011.

WEYLAND, K. et al (eds). Leftist Governments in Latin America: Successes and Shortcomings. Cambridge: Cambridge University Press, 2010.

Recebido em 26/02/14.

Aprovado em 05/05/14. 